\title{
DIMENSI SPIRITUAL KEPEMIMPINAN KH. ABD. WAHID ZAINI DALAM PENGEMBANGAN PROFESIONALITAS DAN KEUNGGULAN KELEMBAGAAN DI PONDOK PESANTREN NURUL JADID PAITON PROBOLINGGO
}

\author{
Abu Hasan Agus R \\ Universitas Nurul Jadid Probolinggo, Indonesia \\ E-mail: masagusrm@gmail.com
}

\begin{abstract}
Abstrak: Tulisan ini akan membahas tentang dimensi spiritual yang dipegang oleh KH. Abdul Wahid Zaini Mun'im dalam mengembangkan lembaga pendidikan di Pondok Pesantren Nurul Jadid, Paiton. Kyai Wahid, begitu dia dipanggil akrab oleh para santrinya, adalah pengasuh ketiga dan perintis banyak lembaga pendidikan formal, lembaga swadaya dan pemberdayaan masyarakat berbasis pesantren, serta lembaga pendidikan tinggi-bersama dengan kakaknya KH. Hasyim Zaini. Secara kepemimpinan, Kyai Wahid adalah sosok paling lengkap secara pengalaman individu; sempat berproses di Nahdlatul Ulama', Partai Politik, dan juga di bidang pendidikan, dia sempat menempuh pendidikan doctoral, meski belum terselesaikan karena 'kepundut' lebih dulu. Apapun itu, Kyai Wahid adalah sosok yang lengkap untuk pengalaman individunya. Maka dari itu, ketika memimpin Pondok Pesantren Nurul Jadid, corak kepemimpinannya seperti within the flow of empowerment process. Kendati, ada pula yang menyebutkan bahwa kepemimpinan Kyai Wahid memiliki dimensi spiritual (dalam makna kegigihan secara religiusitas). Pada bagian inilah, penulis ingin mencoba untuk menghadirkan apa saja keyakinan-keyakinan spiritual dari Kyai Wahid dalam melakukan pengembangan profesionalitas civitas akademik dan membangun nilai keunggulan lembaga formal yang dipimpin dibawah naungan Pondok Pesantren Nurul Jadid.
\end{abstract}

Kata Kunci: Kepemimpinan Spiritual, Profesionalisme, dan Pengembangan Lembaga Unggul.

\section{Pendahuluan}

Kepemimpinan adalah kunci perubahan. Kepemimpinan adalah ruang ekspresi personal dan individual untuk mempengaruhi orang lain mengikuti apa yang diharapkan. Kepemimpinan, dari paradigma teoritik makro, merupakan wujud atau lanskap examplar fenomenologis-antropologis dari sekian treatment seseorang di ruang dan kondisi masing-masing. Sedang, kepemimpian, pada ruang teori mikro, adalah sikap individual mengukur situasi, tantangan, dan model-model menghadapi kenyataan tersebut. Penteori kepemimpinan, akhirnya, berada pada kesimpulan bahwa kepemimpinan tidak bisa distandarisasi dengan cara melokalisasi keadaan, 
perlakuan, dan karakter individu. Semestinya, ada post-standarisasi tentang kepemimpinan yang dihasilkan oleh setiap orang. Ada ruang luas, bagi siapapun, untuk menterjemahkan bagaimana kepemimpinan itu terjadi pada lingkup mereka sendiri-sendiri. ${ }^{1}$

Maka dari itu, sebelum spesifik membicarakan kepemimpinan spiritual (sebagai sebuah produk kajian ilmiah) penulis akan menggambarkan dulu apa sebenarnya yang mereka baca dari kepemimpinan seseorang, bagaimana isntrumentasi yang dilakukan, hingga apa dampak yang dapat dihasilkan pasca melakukan pembacaan secara ilmiah. Terminologi post-standarisasi, menurut Andy Hargreaves dan Dean Frink, berasal dari persoalan suply and demand kepemimpinan di lembaga pendidikan. Menurut mereka, kecenderungan teoritik yang menformulasi tipologi kepemimpinan, menjadi seorang pemimpin harus memiliki kompetensi, profesionalisme, dan pengetahuan tentang kepemimpinan. ${ }^{2}$ Dengan demikian, tidak semua orang mampu menjadi seorang pemimpin (leader), karena dia tidak memiliki latar belakang pengalaman dan pengetahuan kepemimpinan (leadership). Kondisi ini pula menuntut perubahan paradigmatik tentang kepemimpinan. Akhirnya, kedua pakar tersebut memberi keyword tentang kepemimpinan yang berbasis pada poststandirisasi; “...in this sense, is leadership for learning, leadership by learning, and leadership as learning — not leadership for performance and testing". 3

Pemaknaan sederhana kepemimpinan di era post-standarisasi (leadership in age of post-standararisation) adalah perubahan paradigmatik dari public-disclosure ke selfdisclosure. Artinya, kepemimpinan tidak hanya disadari sebagai reduksi pengungkapan publik (masyarakat) bahwa seseorang sudah menjadi pemimpin (leader), melainkan pengungkapan dan refleksi individu (self-reflection) tentang apa pengaruh yang sudah ia berikan kepada pengikutnya. Hal terpenting dalam kajian ini adalah inovasi dan kreatifitas. Seorang pemimpin, pada era post-strandarisasi, harus mampu menterjemahkan lingkungan kerja yang mereka pimpin dan melakukan perubahan-

\footnotetext{
1 Andy Hargreaves \& Dean Fink "Succeeding Leader; Supply and Demand" dalam Robert E White (edited) Principal in Succeesion; Transfer and Rotation In Educational Administration (New York; Springer, 2011), 16

2 Hargreaves \& Fink, Principal in Succeesion, 16

${ }^{3}$ Hargreaves \& Fink, Principal in Succeesion, 18-19

2 | Tarbiyatuna: Jurnal Pendidikan Islam; Volume 11, Nomor 1, Februari 2018 p-ISSN: 2085-6539; e-ISSN: 2242-4579
} 
perubahan, serta mencipta suasana baru (based on creativity) yang membedakan dengan organisasi yang lain.

Karakteristik pengkajian kepemimpinan, berdasarkan kesadaran diri, juga dilakukan oleh Warren Bennis. Warren Bannis, dalam on becoming leader menekankan bahwa menjadi pemimpin bukan dikarenakan proyeksi sains dan ilmu pengetahuan, melainkan karena mereka paham basic kultur dan struktur, dirinya (knowing his self), lingkungannya (knoning bis world), dan mampu mengoprasikan visi, misi, dan tujuannya (operating). ${ }^{4}$ Warren Bennis juga mengatakan "letting the self emerge is esential task for leader". Dia mengutip pun mengukip ungkapa Kurt Lewin "if you want to truly understand something, try to change it". ${ }^{5}$ Adapula ungkapan yang menyebut; "Leadership is specific to the particular situation under investigation. Who becomes the leader of a given group engaging in a particular activity and what the leadership characteristics are in the given case are a function of the specific situation, including the measuring instruments employed. There is a wide variation in the characteristics of individuals who become leaders in similar situations, and an even greater divergence in leadership in different situations ${ }^{\prime 6}$

Berdasarkan pada asumsi teoritik ini, penulis menganggap bahwa kepemimpinan, dengan sekian banyak tajuk klasifikasi teoritik dan temuan di lapangan, merupakan wujud dari dialektika individu dan kondisi sosial yang dihadapi. Sehingga, berdampak pada perubahan pondok pesantren yang cepat beradaptasi, mengadopsi, dan menorobos batas-batas tradisi, merupakan sebagian nilai yang diyakini dalam diri seorang kiai. Atau bahkan, sikap kepemimpinan kiai menjaga serta memelihara konservatisme bukan berarti kiai tersebut tidak mampu menilai keadaan di luar lembaga pendidikan Islam yang dipimpinnya. Melainkan, itulah sikap kekokohan sikap kiai dalam memimpin pesantrennya. Bagi penulis, ada dua fitur umum kepemimpinan kiai; pertama adalah experiental leadership. Yakni seorang pemimpin yang kaya pengalaman. Sebagaimana diketahui, seorang kiai - dalam proses menuju suksesi kepemimpinan - mereka selalu melakukan riblab intelektual

\footnotetext{
4 Sebenarnya ada beberapa fitur lain, kajian leadership berdasarkan pada pemikiran subjektifitas pemimpin itu sendiri. Yang pada intinya, teori-teori tentang kepemimpinan dialihkan dari fenomena yang dideskripsikan sebagai science (phenomena was described) menjadi diri yang dideskripsikan sendiri (self-described). Lihat; Warrent Bennis, On Becoming Leader, 24

${ }^{5}$ Bennis, On Becoming Leader, 23-28

${ }^{6}$ Clive Dimmock et. al, Educational Leadership; Culture and Diversity (London: Sage Publication, 2005), 21
} 
dan spiritual ke beberapa pondok pesantren. Hal ini pernah dideskripsikan oleh KH. Azzaim Ibrahimy pada penulis. Sebelum menjadi pemimpin atau pengasuh, beliau harus belajar ke beberapa pondok pesantren modern, salaf, bahkan konfrehensif. Beliau melakukan riblah dari lembaga lokal hingga nasional. Fenomena kiai melakukan riblah intelektual dan spiritual ini, rupanya, menjadi tradisi khusus kiai untuk mentasbihkan 'anak' atau keluarganya memimpin pondok pesantren yang dikelolanya. $^{7}$

Kedua, eksperimental leadership. Tipologi ini lebih sederhana dideskripsikan. Pasalnya, secara antropologis, terdapat banyak evidence dan postulat ilmiah yang menyebut bahwa seorang kiai di pesantren selalu melakukan perubahan dengan cara mengadopsi, mengadaptasi, dan memperbarui lembaga-lembaga pendidikan di bawah naungan kultur pesantren. Seorang kiai tak 'segan-segan' merubah lembaga pendidikann formal mereka. Misalnya, memasukkan idiom 'Sekolah Islam Unggul' dan “Sekolah Menengah Kejuruan”, bersamaan dengan maraknya item ini di masyarakat urban (perkotaan). Kiai juga seringkali melakukan eksperimentasi pendidikan berdasarkan pengalaman kiai lain. Contoh sederhana, misalnya, KH. Agus Ali Tulangan Sidoarjo. Saat ini, beliau sedang mencoba corak baru idiom pendidikan Islam bernama SMP Progresif Bumi Sholawat. Sebuah sistem pendidikan yang mengintegrasikan intelektualitas dan spiritualisme. Eksperimentasi juga dilakukan di PP. Terpadu Arrisalah Lirboyo Kediri. Berdasarkan pengalaman studi banding teman penulis di pondok pesantren tersebut, menjelaskan bahwa pertama-tama pengasuh PP. Arrisaslah mengadopsi konsep Sekolah Unggul di Jombang, rupanya, sistem itu gagal diimplementasikan dengan baik. Akhirnya, meniru sistem kedisiplinan PP. Darussalam, Gontor. Itupun juga gagal. Akhirnya, PP. Arrisalah, mengimplementasikan sistemnya sendiri mengambil hal yang baik dari Jombang dan Gontor. $^{8}$

Pada dua cerita dan konstruksi kepemimpian serta tradisi yang ada di pondok pesantren inilah, penulis ingin membingkai bagaimana sebenarnya spiritualitas

7 Holilurrahman, "Dialektika-Progresif Kepemimpinan Pesantren dan Integrasi Ilmu Pengetahuan" Jurnal al Afkear, Vol. 1, No. 1 Tahun 2012, 12

8 Lihat; Rudy al Hana "Kebertahanan Pondok Pesantren; antara integrasi dan adaptasi” Jurnal Pendidikan Agama Islam Vol 1 No 2 Tahun 2012, 189 
kepemimpinan (baca; rihlah keagamaan, pendidikan, dan pengalaman) dapat mempengaruhi pilihan kepemimpinan seorang kyai di lingkungan pondok pesantren. Serta, bagaimana nilai-nilai yang diyakini secara individu ini, juga bisa memberikan dampak signifikan pada perubahan yang ada. Untuk membuktikan hal tersebut, penulis akan menjadikan KH. Abdul Wahid Zaini, Pengasuh Ketiga di Pondok Pesantren Nurul Jadid Paiton, sebagai salah satu postulat utamanya. Alasannya sangat sederhana, karena pada periode kepimpinan kyai Wahid, begitu sapaan akrabnya, Pondok Pesantren Nurul Jadid mengalami pengembangan yang sangat banyak; mulai dari guru yang diwajibkan untuk mengabdi secara total, melakukan pengembangan kelembagaan, mencarikan akses para santri untuk berkontribusi pada kehidupan nyata di masyarakat, serta aspek-aspek lainnya yang sudah dilakukan. Selain itu, tentunya, di akhir tulisan penulis akan menghadirkan analisis bahwa ada keyakinan spiritual yang dipegang teguh oleh Kyai Wahid dalam melaksanakan tanggung jawab sebagai pengasuh pondok pesantren tersebut.

\section{Ragam Kajian tentang Kepemimpinan Spiritual}

Kepemimpinan Spiritual, dalam perjalanan konstruksi keilmiahannya, diungkapkan oleh Nada Korac-Kakabadse, Alexander Kouzmin and Andrew Kakabadse ${ }^{9}$, dimulai dari beberapa kajian sebelumnya berupa; servant leadership, ${ }^{10}$ stewardship, ${ }^{11}$ dan empowerment model. ${ }^{12}$ Disamping itu juga ada moral/ethical dan

\footnotetext{
9 Nada Korac-Kakabadse, Alexander Kouzmin and Andrew Kakabadse "Spirituality and leadership \& praxis" dalam Journal of Psycology Vol. 1, No. 2 Tahun 2012

10 Servant leaders embody seven characteristics: they are servants first; articulators of goals (vision); inspiration of trust; knowable in the art of listening; masters of positive feedback (accept a person, not necessarily a person's effort or performance); foresightful (use intuitive sense to bridge information gaps to better foresee the unforeseeable); and are proponents of personal development (the process of change starts in the servant, not out there).

${ }^{11}$ For Block (1996), stewardship is a triumvirate which includes empowerment, brings accountability and balances responsibility through partnerships. Thus, he uses stewardship to address power, control and choice, through empowerment, accountability and partnerships. Block (1996) defines stewardship as the willingness to be accountable for the well-being of large organizations by operating in service, rather than in control of others or, simply, democracy at work - that is, being acceptable and responsible for what is being created without the control of compliance. Block (1996) sees traits and behaviour attributes as prescriptive traps.

12 Bracey et al. (1990) argues that besides competence and confidence,managers also need to be caring and sees the spiritual component of servant leadership as a natural progression in management literature. Bracey et al. (1990) argue that honouring five unspoken employee requests: hear and understand me, even if you disagree with me; please do not make me worry; acknowledge the greatness in me; remember to look for my loving intention; and tell me the truth with compassion, will bring both compassion and acceptability to the workplace.
} 
transformational leadership sebagai bagian constrain awal kepemimpinan spiritual. ${ }^{13}$ Dari cara pandang yang seperti ini kemudian, penulis berkesimpulan bahwa kepemimpinan spiritual adalah sebuah assessment individu untuk sampai pada kehilangan kepentingan individunya (menjadi pelayan bagi masyarakat), memiliki visi dan misi untuk melakukan perubahan-perubahan yang direncanakan, serta terbuka untuk menggali kelemahan individual serta agar dampak dan pengaruh yang ditampilkan tidak banyak menimbulkan resistensi dari para pengikutnya.

Maiko Yasuno mendefinisikan peran spiritual leadership sebagaimana berikut; "spiritual life is...about commitment to a way of thinking and behaving that honors principles of inter-being and interconnectedness" Accordingly, the more aware a person is of the sanctity of the web of life, the more pro-social the person may become. Such a person "broadens one's concept of self, increases the role of morality and strengthens the individual sense of responsibility towards the world" And this sense of responsibility is likely to move people to take action for peace and social justice. The life stories of Gandhi, Martin Luther King Jr., W.E.B. Du Bois, Rosa Parks, Mother Teresa, and many other peace activists are examples of how the inner cultivation of personal spirituality can lead to leadership for social change."14

Kutipan ini bermakna bahwa kehidupan spiritual adalah sebuah komitmen untuk berfikir dan bertindak berdasarkan pada kehormatan prinsipil yang dipegang teguh oleh dia. Memiliki kegigihan dalam upaya untuk menolong orang lain. Mengambil tanggung jawab penuh terhadap perubahan-perubahan yang diinginkan. Dan kekuatan diri agar berada pada ketersiksaan individu meski yang lainnya berada pada posisi yang berbeda. Maiko Yasuno, dengan kongkret memberikan contoh, beberapa pemimpin yang mengorbankan seluruh kehidupan demi mengambil tanggung jawab terhadap kesakitan orang lain.

Khusnurridho, dalam beberapa pertemuan perkuliahannya juga menunjukkan bagaimana agama historisitas Isa di dalam agama Kristen sebagai dari kesejarahan

13 For Burns (1978, p. 46), the moral dimension of the leadership is "its capacity to rescind the claims of the multiplicity of everyday wants, needs and expectations, to respond to the higher levels of moral development and to relate relationship behaviour - its roles, choices, styles and commitments - to a set of reasoned, relatively explicit conscious values". Because of value dimensions, leadership requires a certain kind of character with a certain kind of wisdom in relation to that character (Jearnott, 1989, p. 14). As such, moral leadership presupposes traits of character and qualities of mind. Jearnott (1989, p. 35) defines moral leaders as "self-possessed individuals - possessed of humanity, principles, vision and the craft to make them real".

14 Maiko Yasuno, "The Role of Spirituality in Leadership for Social Change" dalam NewsLetter Spirituality in Education, Vol. 4 Issue 3 June 2008, 3 
kepemimpinan spiritual. Dalam pandangan penulis, harus diakui bahwa ada fakta profetik dari semua Nabi yang diutus kedunia yang memang merelakan kehidupan mereka pada kehidupan orang lain di lingkungan atau umat mereka sendiri. Mereka, para Nabi, tidak memikirkan apa yang baik bagi dirinya, selain apa yang baik bagi jemaah mereka. Maka dari itu, dari sekian kerangka di atas cukup terlihat, bahwa dimensi spiritualitas itu ada pada kesadaran, kegigihan, dan kepasrahan untuk memberikan sumbangsih riil terhadap kehidupan orang lain. Berdasarkan pada faktafakta ini, Paul D. Houston mengatakan:

"From the religious tradition, grace also is a generosity of spirit, a prayer of thanksgiving, and the infinite love of God toward humankind. Most simply, it is a core ingredient of good leadership. One is tempted to point out that amazing leaders show amazing grace. Solid leaders are both effective-they make a difference in their organization-and affective-they make a difference in the lives of those around them. I need not remind anyone working in education today that the work is difficult. It can be grimy and soul-wearying. If it were easy, someone else would be doing it...I believe that in this context we have only two choices: change our careers or connect to the power that we share with others and with the divine. That is why having a spiritual sense of what we do is so important.... We believe that managers do things right and leaders do the right things - but enlightened and empowered leaders do the right things in the right way and for the right reasons. I believe that each of us does the work we do because it is at the core of who we are. That is both the gift and the curse of educational leaders. Our work has such meaning, yet it is hard to separate it from our essence. Before you go somewhere, you not only need to know where you are going, but also who you are on the journey. ${ }^{15}$

Pandangan Paul D. Houdson di atas, yang menceritakan kalau sekolah sebagai tempat suci untuk mengaktualisasikan diri sebagai bagian dari pengabdian dan nilai-nilai spiritualitas seseorang, menurut penulis merupakan pendefinisian paling menarik untuk diaktualisasikan pada konteks lembaga pendidikan. Pandangan ini, dalam cara baca paling sederhana, memiliki makna bahwa seorang pemimpin harus mampu memberikan pencerahan (melalui suri tauladan dan kerangka berfikir yang menyangsikan spiritualitas individu) dan empowerment (penggerakan) orang lain sesuai berdasarkan pada nilai; honesty (kejujuran), kindness (kebaikan perilaku), visionary

15 Paul D. Houdson, Spritual in Educational Leadership (New York, Hope Foundation, 2008), 12 
(memiliki keinginan akhir yang jelas), dan love (kecintaan atau rasa memiliki pada persoalan yang dimiliki oleh seorang bawahan). Thus, pada konteks ini pula penulis beranggapan jika seorang kyai (sacred-person) memiliki nilai-nilai atau instrument bahwa sebagai sosok spiritualitas yang sangat kuat.

\section{Profil KH. Wahid Zaini dan Perubahan Kelembagaan di PP Nurul Jadid}

KH. Abdul Wahid Zaini adalah putra kedua dari tujuh bersaudara, dari pasangan KH. Zaini Mun'im dan Nyai Hj. Nafi'ah. Ia lahir pada hari Jum'at tanggal 17 Juli 1942 di Desa Galis, Pamekasan Madura. Ia mendapatkan pendidikan untuk pertama kalinya, langsung dari ayahandanya tercinta. Sebagai putera, ia sangat patuh dan tawadu' terhadap kedua orang tuanya. Sementara sebagai santri/murid, selain memiliki kecerdasan dan tingkat intelegensia yang tinggi, ia juga sangat tekun mempelajari tiap materi. Menginjak usia dewasa, ia kemudian mondok ke Pesantren Peterongan Jombang, yang kala itu diasuh oleh KH. Musta'in Ramli. Selain mondok, Kiai Wahid muda juga meneruskan jenjang pendidikannya di sekolah Pendidikan Mu'allimin Atas (saat ini menjadi MTs dan MA). Sebagai santri di Pesantren Darul Ulum, selain aktif mengikuti setiap kegiatan kepesantrenan, ia juga turut memikirkan kemajuan Pesantren.

Kala itu Wahid pernah menggagas tentang berdirinya IKDU (Ikatan Keluarga Darul Ulum). Tujuan organisasi ini adalah untuk mengakomodir santri dari berbagai daerah, yang selanjutnya diharapkan bisa memberikan sumbangan, baik pemikiran atau lainnya demi kemajuan Pesantren. Dalam perkembangannya, IKDU berubah menjadi IKAPPDAR (Ikatan Keluaga Besar Pondok Pesantren Darul Ulum). ${ }^{16}$ Memasuki tahun 1962, Kiai Wahid muda melanjutkan proses belajarnya ke jenjang pendidikan yang lebih tinggi, yaitu Institut Agama Islam Negeri (IAIN) Sunan Ampel Surabaya. Ia masuk Fakultas Syari'ah dan memilih Jurusan Akhwal As-Shaksyiah. Saat itu pula, Kiai Wahid muda menyempatkan diri kuliah di Universitas Darul Ulum (UNDAR) Jombang, Fakultas Hukum.

Di IAIN Sunan Ampel, selain menekuni bidang akademik, Kiai Wahid juga terjun dalam dunia organisasi. Kala itu, ia termasuk perintis berdirinya organisasi

${ }^{16}$ Riwayat Singkat Almarhumin PP. Nurul Jadid (Sekretariat PP Nurul Jadid, Probolinggo, 2011), 44

8 | Tarbiyatuna: Jurnal Pendidikan Islam; Volume 11, Nomor 1, Februari 2018 p-ISSN: 2085-6539; e-ISSN: 2242-4579 
PMII. Di organisasi ini, ia dipercaya menjabat sebagai Ketua Komisariat untuk lingkungan kampus IAIN Sunan Ampel Surabaya dan Daerah Surabaya Selatan. Selanjutnya, ia juga dipercaya sebagai Sekretaris dan Ketua Satu untuk Wilayah Jawa Timur (sekarang Koordinator Cabang). Selain aktif di PMII, pada awal tahun 1960an, Wahid juga menempa bakat keorganisasiannya di Ikatan Pemuda Nahdlatul Ulama (IPNU) Wilayah Jawa Timur, dan pada tahun 1964 dipercaya sebagai Koordinator Departemen Mahasiswa dan Perguruan Tinggi Wilayah Jawa Timur.

Selanjutnya, aktivitas Wahid muda bertambah padat. Karena saat itu, selain menjadi Rektor Institut Agama Islam Nurul Jadid (IAINJ) di Paiton Probolinggo, ia juga dipercaya menjadi anggota DPRD tingkat I Provinsi Jawa Timur melalui Partai Persatuan Pembangunan (PPP). Karena padatnya kesibukan ini, maka kewajiban akademis (skripsi) di IAIN Sunan Ampel sempat terbengkalai. Meski demikian, berkat dorongan dari sahabat karibnya, Syaichul Hadi Purnomo, SH, akhirnya Wahid bisa menyelesaikan tugas akhir tersebut. Selesai ujian dengan nilai summa cum laude (sempurna), Kiai Wahid kemudian langsung diwisuda dan meraih gelar Doktorandus (S1) pada periode akademik 1990-1991. Sebelumnya, pada tahun 1984, ia berhasil memperoleh gelar Sarjana Hukum (S1) di Universitas Darul Ulum (UNDAR) Jombang.

Kiai Wahid juga aktif di Nahdlatul Ulama'. Perjuangannya di Nahdlatul Ulama' diawali dengan ajakan kakak kandungnya, KH. Muh. Hasyim Zaini dan adik iparnya, KH. Hasan Abdul Wafi, untuk ikut aktif mengikuti kegiatan di organisasi tersebut. Mulanya, Kiai Wahid mengawali aktivitas keorganisasian di Majelis Wakil Cabang (MWC) NU Paiton. Pada tahun 1971, Kiai Wahid dipercaya menjadi Ketua Umum Tanfidziyah PC NU selama satu periode (1971-1975). Sementara pada periode 1978-1980, 1980-1984 dan 1984-1988, ia dipercaya sebagai Wakil Khatib Syuriyah di Pengurus Wilayah (PW) NU Jawa Timur. Kemudian pada periode 19881992 s/d 1992-1996, ia dipercaya menempati posisi Wakil Rais Syuriyah PW NU Jawa Timur. Sebelum masa jabatannya di PWNU berakhir, ia dipercaya menjadi salah satu Ketua Tanfidziyah Pengurus Besar (PB) NU periode 1994-1999, melalui Muktamar NU ke-29 di Cipasung Jawa Barat tahun 1994. 
Kiai Wahid menikah dengan Nyai Hj. Zubaidiyyah Toha dan dianugerahi delapan putra-putri, yaitu: 1) KH. Abdul Hamid Wahid, 2) Eny Halimiyah Wahid, 3) Nur Diana Kholidah Wahid, 4) Najiburrahman Wahid, 5) Fitroh Hanifiyyah Wahid), 6) Hilyah Masunah Wahid, 7) Sholahuddin Wahid dan 8) Mudarik Wahid. ${ }^{17}$ Pada tanggal 18 Sya’ban $1421 \mathrm{H}$ (tahun 2000), tanpa ada firasat apa-apa, tiba-tiba Kiai Wahid meninggal dunia. Wajar jika para santri, keluarga, alumni, masyarakat sekitar pesantren, tokoh agama, masyarakat dan pemerintah mengalami kidung duka cita.

KH Abdul Wahid Zaini sebagai pengasuh ketiga periode 1984-2000 melakukan beberapa strategi yang di lakukanNya, hal ini akan diuraikan sebagai berikut : Strategi pertama melalui kelembagaan, hal ini tergambar dengan penguatan dan pembenahan lembaga tinggi di tingakat Pondok Pesantren Nurul Jadid, seperti :

1. Penguatan Yayasan Nurul Jadid sebagai lembaga tertinggi yang bertanggung jawab mengawal lembaga pendidikan yang ada di bawah naungan Pondok Pesantren Nurul jadid.

2. Penguatan Koordinatorat (sekretariat) sebagai lembaga pusat informasi dan adminitrasi untuk menjadi penyimpanan data yang berkaitan dengan adminstrasi Yayasan dan Pesantren terutama yang berkenaan dengan pendidikan di Pondok Pesantren Nurul Jadid.

3. Penguatan Biro Pendidikan sebagai lembaga yang mengawal jalanNya pendidikan formal dan non formal di Pondok Pesantren Nurul Jadid, lembaga ini dalam arti lain sebagai pembantu dari Yayasan Nurul Jadid.

4. Penguatan Biro Kepesantrenan sebagai lembaga untuk menjalankan kegiatan keagamaan di Wilayah atau Asrama Santri.

Sedangkan pembenahan lembaga lain yang sebelumnya tidak ada, seperti :

1. Pembanahan Biro Pengembangan Pesantren dan Masyarakat (BPPM), lembaga ini sebagai penggerak kegiatan baik di lembaga pendidikan ataupun di Wailayah atau Asrama, lembaga ini juga sebagai penyambung lidah dalam Pesantren dan luar Pesantren.

${ }^{17}$ Saily Aswi dkk, Riwayat Singkeat Almarhumin PP. Nurul Jadid (Sekretariat PP Nurul Jadid, Probolinggo, 2011), 45 
2. Pembanahan Pembantu Pengurus Pondok Pesantren Nurul Jadid (P4NJ), lembaga ini dibuat sebagai pembantu kepengurusan di Pondok Pesantren Nurul Jadid dikala ada kesulitan untuk mengambangkan pendidikan di dalam Pesantren ataupun di luar Pesantren. $^{18}$

Adapun tugas pokok masing-masing lembaga, seperti ;

1. Yayasan Nurul Jadid Yayasan dengan tugasnya yang lebih mengarah kepada penyediaan sarana fisik Pesantren, dan Departemen Pendidikan, meliputi pendidikan formal dan Non formal yang ada di Pondok Pesantren, lembaga ini merupakan lembaga tertinggi yang dibawah naungan Pondok Pesantren Nurul Jadid.

2. Koordinatorat/Sekretariat Koordinatorat (sekarang menjadi sekretariat), fungsinya sebagai Pusat Perencanaan Program dan Pusat Administrasi Pesantren dan Yayasan, lembaga ini merupakan lembagan yang sangat dibutuhkan dalam rangak membantu Pesantren, baik dalam perencanaan, pengawalan dan pengembangan Pesantren kedepan.

3. Biro Pendidikan Berfungsi sebagai komando dalam Pengelola Pendidikan di tingkat kelembagaan baik Formal ataupun non Formal, lembaga ini sebagai lembaga pembantu dari Yayasan Nurul Jadid dalam menjalankan dan meningkatan Pendidikan di Pesantren.

4. Biro Kepesantrenan Mempunyai tugas ditingkat kepesantrenan dalam teknis Pengawalan kegiatan di Pesantren, baik pengawalan Santri di Wilayah atau Asrama.

5. Biro Pengembangan Pesantren dan Masyarakat (BPPM) Mempunyai tugas dalam pengembangan Pesantren dan Pemberdayaan Masyarakat, lembaga ini berfungsi sebagai penyambung antara Pesantren, Masyarakat dan intsnasi Pemerintahan di luar Pesantren dalam rangka memperkuat hubungan antara keduanya. ${ }^{19}$

Sebagai pengasuh, KH Abdul Wahid Zaini menerapkan beberapa strategi ini terlihat dari corak semangatnya dalam meningkatkan pendidikan di Pondok Pesantren Nurul Jadid dan kepemimpinannya yang demokratis serta menghargai

${ }_{18}$ KH. Moh Zuhri Zaini, Pengasuh PP. Nurul Jadid Wawancara, Probolinggo 16 April 2016

${ }^{19}$ KH. Najiburrahman Wahid, Wawancara, Probolinggo, 20 April 2016. 
semua kalangan di tingkat Pesantren dan lembaga, sampai tingkat bawah sekalipun. Seperti ketika beliau akan mengambil keputusan selalu melalui rapat dengan pengurus Pesantren yang ada kaitanya dengan Pesantren dan melalui pimpinan lembaga yang ada kaitanNya dengan lembaga, baik yang berupa hal strategis maupun teknis. ${ }^{20}$

Strategi ini dianggap penting oleh KH. Abdul Wahid Zaini untuk keterlibatan aktif antara pimpinan lembaga dan Pengurus Pesantren dalam rangka mencapai tujuan yang diinginkan bersama. Dengan demikian, baik Pemimpin atau pun pengikut mengambil tanggungjawab pribadi (personal responsibility) untuk mencapai tujuan bersama tersebut. ${ }^{21}$ Dalam bidang pendidikan, dilakukan pembenahan mulai dari TK (Taman Kanak-Kanak) hingga Perguruan Tinggi. Di antaranya, pada tahun 1989, setelah Pesantren Nurul Jadid menjalin kerjasama dengan Perkumpulan Keluarga Berencana Indonesia (PKBI), TK Nurul Muni'm kemudian dirubah menjadi TK. Bina Anaprasa. Satu tahun kemudian, beberapa lembaga pendidikan yang sebelumnya hanya memiliki status terdaftar dan diakui, diusahakan menjadi disamakan. Dengan peningkatan status ini, lembaga pendidikan tersebut sejajar dengan Lembaga Pendidikan Negeri.

"Di antara lembaga tersebut adalah SMUNJ (disamakan pada tahun 1990), SMPNJ (disamakan pada tahun 1991), dan MTsNJ serta MANJ (disamakan pada tahun 1997). Pada tahun 1992, di Pesantren Nurul Jadid juga telah dirintis berdirinya Madrasah Aliyah Program Keagamaan (MAPK). Ini ditujukan untuk meningkatkan kemampuan anak didik memahami kitab klasik dan juga mampu berbahasa asing (arab dan inggris). Pada tahun 1995, berdasarkan kurikulum baru, MAPK berubah menjadi MAK". ${ }^{22}$

Sementara itu, upaya-upaya pengembangan juga dilakukan pada jenjang Perguruan Tinggi, seperti perubahan status dari PTID menjadi Institut Agama Islam Nurul Jadid (1986). Ini karena konsentrasi keilmuan di tubuh PTID bertambah menjadi tiga Fakultas, yaitu Fakultas Dakwah, Tarbiyah dan Syari'ah dengan dua jurusan pada masing-masing fakultas. Kemudian pada tahun 1999, masing-masing fakultas tersebut lolos akreditasi Badan Akreditasi Nasional (BAN). ${ }^{23}$

20 Profil Pondok Pesantren Nurul Jadid, Koordinatorat PP. Nurul Jadid, Probolinggo, 2010.

${ }^{21}$ KH. Abdul Hamid Wahid, Wawancara, Probolinggo, 25 April 2016

22 KH. Abdul Hamid Wahid, Wawancara, Probolinggo, 25 April 2016

23 Profil Singkat Institut Agama Islam Nurul Jadid, IAI Nurul Jadid, Probolinggo, 2010, 4

12 | Tarbiyatuna: Jurnal Pendidikan Islam; Volume 11, Nomor 1, Februari 2018 p-ISSN: 2085-6539; e-ISSN: 2242-4579 
Selanjutnya, untuk menjawab tantangan dalam bidang Information Technology (IT), pada tahun 1999 didirikan STT (Sekolah Tinggi Teknologi) Nurul Jadid yang semula hanya berupa kursus komputer. ${ }^{24}$ Pada masa Kiai Wahid juga didirikan Lembaga Pengembangan Bahasa Asing (LPBA) yang menjadi cikal bakal pendidikan D1 Bahasa Inggris. LPBA diharapkan dapat menghidupkan gairah berbahasa asing di masing-masing Wilayah atau Gang. Sementara itu, berbagai upaya mendorong kemandirian masyarakat sekitar Pesantren juga digalakkan. Misalkan, melalui Biro Pengembangan Pesantren dan Masyarakat (BPPM), Pesantren Nurul Jadid antara lain mendirikan USP (Unit Simpan Pinjam) yang dirintis tahun 2000, guna membantu para petani tembakau dan juga memberikan pendampingan pada mereka. Ide ini muncul karena petani tembakau di sekitar Paiton tidak memiliki posisi tawar yang kuat di hadapan para pengambil kebijakan. Padahal tembakau merupakan sumber utama ekonomi masyarakat Paiton. Melalui Paperton, Pesantren dan masyarakat bermusyawarah seputar persoalan-persoalan pertembakauan, seperti kapasitas produksi, kapasitas daya tampung gudang dan lain-lain.

Sementara untuk membantu masyarakat memperoleh pelayanan kesehatan yang baik, Pesantren Nurul Jadid juga mendirikan BP (Balai Pengobatan) AzZainiyah yang semula bernama Usaha Pelayanan Kesehatan Santri (UPKS). Pada masa Kiai Wahid juga didirikan panti asuhan untuk menampung anak-anak dari kalangan ekonomi lemah. ${ }^{25}$ Menurut hasil wawancara dengan KH. Najuburrahman Wahid, putera KH. Abdul Wahid Zaini mengatakan:

"Peningkatan atau pengembangan mutu atau kulitas pendidikan di Pondok Pesantren Nurul Jadid ini, Kiai Wahid lebih fokus pada pembenahan dulu, seperti pembenahan lembaga pendidikan serta penyamaan status kelembagaan seperti di atas, akan tetapi lambat laun kulitas juga beliau lakukan. Untuk melakukan peningkatan kualitas pendidikan Pesantren, Kiai Wahid turun lapangan dalam rangka melihat pendidikan di Pesantren, baru setelah itu langsung dilakukan",26

Strategi Kedua melalui penguatan Sumber Daya Manusia (SDM) kepengurus Pesantren dan pimpinan lembaga di bawah naungan Yayasan Nurul Jadid, penguatan

24 Profil Sekolah Tinggi Teknologi Nurul Jadid, Probolinggo, 2011, 6

${ }^{25}$ KH. Abdul Hamid Wahid, Wawancara, Probolinggo, 25 April 2016

${ }^{26}$ KH. Najiburrahman Wahid, Wawancara, Probolinggo, 20 April 2016. 
SDM ini di dilakukan dengan cara memberikan bimbingan, mengadakan kajiankajian, mendelegasikan Pengurus Pesantren dan pimpinan lembaga untuk mengikuti pelatihan di luar Pesantren. Hal ini tergambar ketika KH. Abdul Wahid Zaini melibatkan kepengurusan Pesantren dan pimpinan lembaga untuk mencapai tujuan yang diinginkan bersama dalam upaya peningkatan mutu pendidikan di Pondok Pesantren Nurul Jadid.

Kiai Wahid memberikan gambaran tentang tanggung jawab seseorang pada Hadist Nabi yang disabdakan diatas. Tidak akan berhasil dan tercapai seuatu keinginan tanpa dikawal dan didukung berasama-sama, baik dari pemimpin dan aggota ataupun sebaliknya anggota dengan pemimpin. Strategi ketiga melalui jaringan Organisasi Sosial Kemasyrakatan, hal ini dilakukan dalam rangka terjalinnya kerjasama yang strategis dan bersifat jangka panjang dengan Kementerian Agama (KEMENAG) dan Menteri Kebudayaan dan Pendidikan (MENDIKBUD) dalam upaya peningkatan pendidikan di Pondok Pesantren Nurul Jadid. Oleh karena itu, tak heran jika pada masa Kiai Wahid, program-program Pondok Pesantren Nurul Jadid mengalami kemajuan. Karena pondok ini dipimpin oleh orang yang banyak memiliki jaringan atau relasi luas. Sehingga pesantren tak berjalan sendirian dalam mensukseskan tujuannya. Strategi Keempat yang dilakukan oleh KH. Abdul Wahid Zaini dalam meningkatkan mutu pendidikan di Pondok Pesantren Nurul Jadid adalah mengoprasionalkan Visi dan Misi Pondok Pesantren Nurul Jadid yang berbasis Trilogi Santri dan Panca Kesadaran Santri, strategi ini merupakan pembinaan dan pengembangan untuk menjadi manusia religius, intelektual dan profesional dan mampu berfikir kedepan dengan berperilaku yang mencerminkan budaya kesantrian, selektif, cakap, dan terampil dalam menghadapi dan menyelesaikan setiap permasalahan baik Individu maupun organisasi dalam kehidupan bermasyarakat, berbangsa dan bernegara, terutama di Bidang Pendidikan. ${ }^{27}$

Adapun Visi dan Misi Pondok Pesantren Nurul Jadid sebagai berikut: Visi "Terbentuknya manusia yang beriman, bertaqwa, berakhlakul karimah, berilmu, berwawasan luas, berpandangan kedepan, cakap, terampil, mandiri, kreatif, memiliki

${ }^{27}$ KH. Moh. Zuhri Zaini, Pengasuh PP Nurul Jadid, Kajian Trilogi dan Panca Kesadaran Santri dalam Orientasi Santri Baru 2014, Probolinggo, 26 Juni 2014

14 | Tarbiyatuna: Jurnal Pendidikan Islam; Volume 11, Nomor 1, Februari 2018 p-ISSN: 2085-6539; e-ISSN: 2242-4579 
etos kerja, toleran, bertanggung jawab kemasyarakatan serta berguna bagi Agama, Bangsa dan Negara".

Sedangkan Misi Pondok Pesantren Nurul Jadid antara lain:

1. Penanaman keimanan, ketaqwaan kepada Allah dan pembinaan akhlakul karimah.

2. Pendidikan keilmuan dan pengembangan wawasan.

3. Pengembangan bakat dan minat.

4. Pembinaan keterampilan dan keahlian.

5. Pengembangan kewirausahaan dan kemandirian.

6. Penanaman kesadaran hidup sehat dan kepedulian terhadap lingkungan.

7. Penanaman tanggung jawab kemasyarakatan dan kebangsaan.

Trilogi Santri :

1. harus berpegang teguh pada kewajiban fardhu ain

2. Mawas diri dengan meninggalkan dosa-dosa besar

3. Berbudi luhur pada Allah dan makhluk

Panca Kesadaran Santri

1. Kesadaran Beragama

2. Kesadaran Berilmu

3. Kesadaran Berorganisasi

4. Kesadaran Bermasyarakat

5. Kesadaran Berbangsa dan Bernegara).

Strategi melalui kepemimpinan kolektifitas, Pada masa kepemimpinan $\mathrm{KH}$. Abdul Wahid Zaini (1984-2000), Pondok Pesantren Nurul Jadid mengalami perkembangan yang sangat pesat, baik mengenai pendidikan Pesantren, jumlah santri maupun pelayanan dan pengembangan kemasyarakatan. Sebagai pengasuh Pesantren, selain dibantu adik-adiknya, ia juga dibantu oleh KH. Hasan Abd. Wafi yang kala itu dipercaya sebagai Dewan Pengawas Pesantren, dan KH. Fadlurrahman serta KH. Faqih Zawawi sebagai Dewan Pertimbangan Pesantren. KH. Abdul Wahid Zaini ketika mau menetukan segala perioritas yang berkenaan dengan pendidikan Pesantren 
selalu melibatkan jajaran Pengasuh dan Dewan Pengasuh Pondok Pesantren Nurul Jadid. $^{28}$

Disamping itu KH. Abdul Wahid Zaini adalah Pengasuh ketika dari empat jajaran Pengasuh Pondok Pesantren Nurul jadid, Pengasuh pertama sekaligus Pendiri KH. Zaini Abdul Mun'im, kedua KH. Moh. Hasyim Zaini dan KH. Abdul Wahid Zaini, sebagai penerus Pengasuh Pondok Pesantren Nurul Jadid di pimpin oleh adik kandungnya yaitu KH. Moh. Zuhri Zaini. Selama menjadi Pengasuh Kiai Wahid sering mengadakan rapat bersama Dewan Pengasuh dan Dewan Pertimbagan Pengasuh. Pada masa kepemimpinan Kiai Wahid (1984-2000) Pondok Pesantren Nurul Jadid mengalami perkembangan yang sangat pesat, baik mengenai jumlah santri maupun pelayanan dan pengembangan kemasyarakatan. Sebagai Pemimpin Pesantren, selain dibantu adik-adiknya ia juga dibantu oleh KH. Hasan Abd. Wafi yang kala itu dipercaya sebagai Dewan Pengawas Pesantren dan KH. Fadlurrahman serta KH. Faqih Zawawi sebagai Dewan Pertimbangan Pesantren.

Selama menjadi Pengasuh Pesantren Nurul Jadid, Kiai Wahid tidak hanya mengarahkan para santrinya agar mampu memahami ilmu-ilmu Agama saja, tapi juga Teknologi bahkan kemampuan menciptakan kemandirian masyarakat sekitar Pesantren lewat pendidikan, ekonomi dan kesehatan. Pendidikan dan pembinaan Santri Nurul Jadid dilaksanakan selama 24 jam dalam kurun waktu selama santri berada di Pondok Pesantren Nurul Jadid, maka pendidikan dan pembinaan santri dilaksanakan dalam serangkaian proses yang melalui beberapa fase yang saling terkait. Yang meliputi : pertama Orientasi Masuk Adalah merupakan kegiatan pra kondisi yang dilakukan terhadap santri baru. Proses pembinaan awal ini, dilaksanakan sebelum memasuki proses pendidikan dan pembinaan. Pada kegiatan ini sudah mulai dilakukan pemetaan kemampuan serta bakat dan minat santri. Adapun tujuan dari orientasi masuk ini adalah untuk mengenal, memahami, menerima dan menyesuaikan dengan kondisi di Pondok Pesantren Nurul Jadid. Kegiatan ini diisi dengan; Materi Pre test, Prasyarat dan motivasi mencari ilmu di Pondok Pesantren, Nilai-nilai dasar dan Tradisi Pesantren, Sejarah Pesantren, tata tertib Santri, Organisasi Pesantren,

\footnotetext{
${ }^{28}$ KH. Faiz AHZ, Profil Pondok Pesantren Nurul Jadid, Koordinatorat PP Nurul Jadid, Probolinggo, 2010, 18 
Kurikulum Pesantren, Seputar lingkungan Pesantren, Panca Kesadaran dan Trilogi Santri, Aurod yaumiyyah, Post test, Baiat

Kedua, Masa Pendidikan dan Pembinaan Masa pendidikan dan pembinaan ini merupakan inti dari pada proses thalab al-ílmi santri selama mondok di Pondok Pesantren Nurul Jadid. Masa pendidikan dan pembinaan dilaksanakan selama 24 jam selama santri mondok di Pondok Pesantren Nurul Jadid. Pada proses ini kemampuan dasar yang harus dimiliki santri Pondok Pesantren Nurul Jadid adalah kemampuan Al-Furud Al-'Ainiyah yang meliputi Aqidah, Syariah dan Akblak. Untuk kemampuan yang bersifat pengembangan dilakukan di asrama dan kegiatan akstra kurikuler di sekolah yang berupa kegiatan osis atau FKO dan Presma. Selain itu dilaksanakan Student Day yang dilaksanakan pada setiap malam selasa, malam Jum'at dan hari jum'at yang ditangani oleh masing-masing Organisasi Daerah. ${ }^{29}$

Dalam rangka menumbuhkan semnagat belajar Santri Nurul Jadid, maka ditetapkan pelajaran lokal tentang doktrin yang dilakukan pada kegiatan ekstra maupun intra pada pendidikan formal maupun kegiatan Kepesantrenan. Materi Pendidikan dan Pembinaan, Pengembangan Ilmu-Ilmu Keagamaan Pengembangan Ilmu-Ilmu Pengetahuan, Pendidikan Skill dan Keterampilan, Pendidikan Kewirausahaan, Pendidikan Bela Diri, dan Materi Doktrin Meliputi: Filosofi Dasar Doktrin, Panca Kesadaran Santri Trilogi Santri, Contoh-Contoh Kasus. ${ }^{30}$ Kegiatan Pendidikan Formal, Kegiatan Kepesantrenan, Kegiatan Kursus, Kegiatan Student Day, kegiatan pengajian wetonan, kegiatan kelompok sorogan Kegiatan Pendidikan Formal. Adalah kegiatan belajar yang dilakukan di Lembaga Pendidikan melalui tatap muka yang alokasi waktunya telah ditentukan dan diperdalam dengan tugastugas. Adapun kurikulum pada kegiatan pendidikan formal disesuaikan dengan Kurikulum DEPAG untuk jenjang Pendidikan Tingkat MI, MTs, MA dan IAI. Nurul Jadid dengan spesifikasi keagamaan serta Kurikulum DEPDIKNAS dengan spesifikasi umum, untuk tingkat pendidikan SMP, SMA dan STT.

"Dalam rangka membentuk karakteristik santri Pondok Pesantren Nurul Jadid, maka perlu ada penanaman doktrin yang ditanamkan melalui kurikulum pada pelajaran lokal tentang doktrin. Kegiatan ini dilakukan pada

29 Pedoman Pelaksanaan Orientasi Santri Baru, PP. Nurul Jadid, 2010, 12

${ }^{30}$ KH. Abdul Hamid Wahid, Wawancara, Probolinggo, 25 April 2016 
kegiatan ekstra maupun intra pada pendidikan formal maupun kegiatan kepesantrenan. Materi dotrin disesuaikan dengan jenjang pendidikan pada masing-masing lembaga". ${ }^{31}$

Setiap strategi mengandung kegiatan yang harus dilaksanakan untuk mewujudkan tujuan yang telah ditentukan. Kegiatan ini pada intinya adalah menggerakkan semua komponen lembaga pendidikan di bawah naungan Yayasan Nurul Jadid yang bermuara pada peningkatan mutu pendidikan. ${ }^{32}$ Membangun kapasitas level Pemerintahan. Membangun kapasitas level Pemerintahan berarti mengembangkan suasana kerja di kalangan staf dan pegawai kantor pendidikan di lembaga pendidikan yang di bawah naungan yayasan Nurul Jadid, yang menekankan pada penciptaan kondisi kerja yang didasarkan pada saling percaya mempercayai untuk dapat melayani sebaik mungkin, agar lembaga pendidikan dapat mengelola Proses Belajar Mengajar (PBM) dan meningkatkan mutunya masing-masing sesuai dengan kondisi dan situasi yang ada. Variable yang diperluakan dalam pengembangan kapasitas Pemerintahan antara lain visi, skills, incentive, sumber daya, dan program. ${ }^{33}$

Di bidang infrastruktur, pembangunan kapasitas pada level Pemerintahan ini, keberadaan operation room mutlak diperlukan. Pada operation room paling tidak memiliki peta pesantren dan kualitasnya, peta guru, jumlah, penyebaran, kesesuaian, dan kualifikasi pendidikannya dan data yang senantiasa dimutakhirkan dari tahun ke tahun. Disamping itu diperlukan juga suatu system, mekanisme dan dan prosedur pelatihan, pemilihan, pengangkatan dan pemberhentian kepala sekolah dan pengawas. Berdasarkan data dan fakta yang ada pada operation room bias dikembangkan berbagai scenario peningkatan mutu pendidikan, mutu Kepala Sekolah, mutu Guru, di suatu lembaga di bawah naungan Yayasan Nurul Jadid. Di samping itu, dalam pembangunan kapasitas sekolah pada level Pemerintahan perlu dikaji dan ditentukan scenario bagaimana pemberdayaan guru, pengembangan dan peningkatan kemampuan guru secara berkesinambungan dilaksanakan. Dalam peningkatan mutu guru harus ditekankan pada pemberdayaan dan pendinamisian KKG, MGMP, dan MKKS. Dinamisasi ini ditujukan ubtuk dua hal, yaitu; a0 meningkatkan interaksi

${ }^{31}$ KH. Abdul Hamid Wahid, Wawancara, Probolinggo, 25 April 2016

32 KH. Abdul Hamid Wahid, Wawancara, Probolinggo, 25 April 2016

33 KH. Abdul Hamid Wahid, Wawancara, Probolinggo, 25 April 2016

18 | Tarbiyatuna: Jurnal Pendidikan Islam; Volume 11, Nomor 1, Februari 2018 p-ISSN: 2085-6539; e-ISSN: 2242-4579 
akademik antara guru dan kepala sekolah, b) untuk mengembangkan kemampuan di kalangan guru melalui refleksi secara sistematis atas apa yang dilakukan dalam proses belajar mengajar.

Dalam aspek pengembangan tenaga pendidikan ini pula harus mempersiapkan rancangan pengadaan gueu, baik karena lingkaran proses pensiun sudah mulai muncul maupun perluasan pelayanan pendidikan yang semakin lebar, sehingga penambahan lembaga pendidikan baru tidak dapat ditunda lagi. Peningkatan kemapuan profesioanalitas guru yang harus dimiliki oleh guru ada emapat sasaran, yaitu; 1) kemampuan melaksanakan PBM secara individual, 2) kemampuan melaksanakan PBM dan mengembangkan kurikulum secara berkelompok, 3) kemampuan mengorganisir, memimpin, menjalin, hubungan, dan memecahkan masalah secara individual dan, 4) kemampuan untuk bekerjasama memajukan sekolah. ${ }^{34}$ Membangun kapasitas level lembaga pendidikan yang berada di dalam Pesantren. Membangun kapasitas berarti membangun kerjasama, membangun terus, dan membangun kelompok atau masyarakat sehingga memiliki persepsi yang sama kemana akan menuju dan dapat bekerjasama untuk mewujudkan tujuan itu. Membangun kapasitas diarahkan pada sekolah yang berada di dalam pesantren sebagai suatu system dan sebagai inti dari sekolah. Secara teoritis dalam membangun kapasaitas pesantren ada beberapa konsep yang diidentifikasi, yaitu; pertama, dalam membangun kapasitas pesantren individu memegag peranan penting. Individu dalam hal ini bias kepala sekolah, guru ataupun siswa. Kedua, hubungan dan kaitan kerja diantara individu-individu yang dirangkum dalam suatu aturan sehingga mereka dapat bekerja sebagai suatu tim yang solid. Ketiga, terdapat suatu system dan meanisme yang mendorong dan memfasilitasi terjadinya kesatuan kerja dan jaringan kerja internl yang akan meningkatkan kemampuan individu dan kauitas kerjasama.

Keberadaan pemimpin yang mampu mengembangkan nilai-nilai, kultur, trust, keutuhan social, dan kebersamaan yang tulus. Jadi membangun kapaistas mencakup membangun diri idividu, kelompok dan organisasi di satu sisi dan membangun kepemimpinan di sisi lain. Membangun kapasitas level lembaga pendidikan di dalam

${ }^{34}$ KH. Abdul Hamid Wahid, Wawancara, Probolinggo, 25 April 2016 
pesantren mencakup; mengembangkan visi dan misi, mengembangkan kepemimpinan dan manajemen sekolah, mengembangkan kultur sekolah, dan melibatkan orang tua, alumni dan masyarakat serta memahami tantangan yang dihadapi kepala sekolah. ${ }^{35}$ Upaya peningkatan mutu pendidikan santri dilaksanakan melalui dua hal, yaitu : Standar Mutu Santri. Secara kognitif, standar mutu santri yang digunakan lembaga pendidikan di Pondok Pesantren Nurul Jadid berupa pencapaian nilai angka 7,0 murni dalam setiap mata pelajaran. Secara afektif, standar kompetensi yang harus dicapai adalah memiliiki nilai-nilai etika, estetika, demokrasi, toleransi, dan humaniora dengan dilandasi keimanan dan ketaqwaan kepada Allah SWT serta mampu bertingkah laku secara syar'i sesuai dengan tuntunan ajaran Islam sehingga akan mencapai muslimah shalihah kamil (utuh) sosial. Secara psikomotorik, standar kompetensi santri yaitu memiliki ketrampilan berkomunikasi, kecakapan hidup dan mampu beradaptasi dengan perkembangan lingkungan sosial budaya dan lingkungan alam baik lokal maupun regeonal.

Selanjutnya, perbaikan Sumber Daya Manusia yaitu Ustadz dan Santri Program perbaikan mutu ustadz antara lain pengadaan program workshop dewan asatidz, Musyawarah. Ustadz Mata Pengajian (MUMP), seminar berkala, dan pembuatan karya ilmiah. Perbaikan mutu santri antara lain adanya beberapa program seperti tes masuk madrasah, praktek pengalaman mengajar (PPM), pembuatan karya ilmiah (tugas akhir), halaqah bahtsul masail al haditsah (musyawarah pembahasan masalah-masalah terkini), pemberian penghargaan kepada santri berprestasi, latihan khitobah (latihan pidato 4 bahasa: bahasa Arab, Jawa, Inggris dan Indonesia), dribaiyyah (bershalawat kepada Nabi Muhammad SAW dengan menggunakan lagu atau nada), membaca tablil, halaqoh al-ta'lim atau majlis ta'lim, sorogan kitab dan al Qur'an, daurah ilmiah dan kajian tematik. Kegiatan ini dilakukan baik secara kelompok ataupun individual. ${ }^{36}$

\section{Analitycal Framework: KH. Wahid Zaini on Becoming Spiritual Leadership}

Para peneliti pesantren, seperti Hiroko Horikusi, Endang Turmudzi, Imam

${ }^{35}$ KH. Najiburrahman Wahid, Wawancara, Probolinggo, 20 April 2016.

${ }^{36}$ KH. Najiburrahman Wahid, W awancara, Probolinggo, 20 April 2016

20 | Tarbiyatuna: Jurnal Pendidikan Islam; Volume 11, Nomor 1, Februari 2018 p-ISSN: 2085-6539; e-ISSN: 2242-4579 
Suprayogo, Ali Machsan Moesa, dan para peneliti lainnya, menspesifikasi bahwa kyai bukan sebuah terminology biasa. Kata kiai memiliki arti yang sangat luas. Bahkan, berdasarkan keyakinan orang jawa, bahasa Kiai tidak bisa diterjemahkan dengan bahasa lain, terkecuali kata Kiai itu sendiri. Gus Mus, sapaan akrab KH Mustofa Bisri, pernah berujar dalam suatu ceramah, bahwa terjemahan kata kiai dengan bahasa ulama', bukan karena ulama' dan kiai memiliki kesamaan fungsi dan peran dari sisi kebahasaan, melainkan karena bahasa ulama' dianggap mewakili sebagian peran kiai, yakni ahli ilmu agama. Dalam pandangannya, kata kiai bisa bermakna ulama', syaikh, ahli ibadah, pelayan masyarakat, dan ahli hukum Islam. Rupanya ungkapan Gus Mus selaras dengan hasil-hasil penelitian para ilmuan.

Manfred Ziemek menyebutkan kiai bukan berasal dari bahasa Arab, namun bersumber dari bahasa Jawa kuno "kiya-kia" yang artinya orang yang dihormati. Sedangkan sebutan kiai dalam bahasa Jawa digunakan untuk tiga jenis gelar yang berbeda: a) sebagai gelar kehormatan bagi sesuatu yang dianggap keramat, seperti "Kiai Garuda Kencana" digunakan untuk sebutan kereta emas yang ada di keraton Ngayogyakarta; b) sebagai gelar kehormatan untuk orang tua pada umumnya; c) sebagai gelar yang diberikan oleh masyarakat kepada ahli agama Islam yang menjadi pimpinan pesantren dan mengajar kitab kuning kepada santrinya. ${ }^{37}$ Nurcholish Madjid menyempitkan makna dengan menyebut bahwa kiai berasal dari bahasa Jawa yahi yang berarti tua atau kakek. Hal tersebut didasarkan oleh penghormatan kepada seorang yang dianggap lebih tua, sebagaimana kecenderungan umum dalam masyarakat Jawa, dan memiliki kesepadanan makna dan fungsi dengan kata syaikh (orang tua/guru) dalam bahasa Arab. ${ }^{38}$

Secara terminologis Koentjaraningrat, mengatakan kiai adalah pendiri dan pemimpin sebuah pesantren sebagi Muslim terpelajar yang membaktikan hidupnya demi Allah SWT', serta menyebarluaskan dan mendalami ajaran dan pandangan Islam melalui kegiatan pendidikan. ${ }^{39}$ Figur dan sosok kiai menjadi elemen paling vital dalam dunia pesantren yang bercorak paternalistik. Hasbullah mengemukakan bahwa

\footnotetext{
${ }^{37}$ Manfred Ziemek, Pesantren dalam Pmbaharuan Sosial, Transleted By Butche B Soendjojo (Jakarta: P3M. 1986), 130. 38 Nurcholish Madjid, Bilik-Bilik Pesantren (Jakarta: Paramadina. 1997), 20.

${ }^{39}$ Koentjaraningrat, Kebudayaan Jawa (Jakarta: Balai Pustaka, 1984), 34.
} 
perkembangan dan kelangsungan hidup suatu pesantren banyak bergantung pada keahlian dan kedalaman ilmu serta kharisma dan wibawa kiai dalam mengelola pesantrennya. ${ }^{40}$ Kebanyakan kiai adalah seorang pendiri dan pemiliki tunggal sebuah pesantren. $^{41}$ Kiai sebagai pendiri dan pemimpin pondok pesantren memiliki kewenangan penuh untuk mengelola pesantren yang telah didirikannya. ${ }^{42}$ Dalam pembelajaran di pesantren, kiai bertindak sebagai perencana, pelaksana, dan pengevaluasi tehadap semua kegiatan di pesantren. Keberadaan kiai di pesantren menurut Dawam Raharjo mempunyai otoritas dan wewenang untuk menemukan serta mengarahkan semua bentuk pendidikan dan kehidupan agama atas tanggungjawabnya sendiri. ${ }^{43}$

Pemaknaan kiai berdasarkan pada pandangan para peneliti di atas membuktikan bahwa kata kiai bukanlah kata sederhana untuk diterjemahkan ke bahasa lain. Meskipun secara faktual, sebagian masyarakat jawa, memahami dialek kata "Kiai" tersebut tanpa perlu dijelaskan teorinya. Penyebabnya karena peran kiai masih bisa dirasakan di masyarakat dan berubah-ubah sesuai dengan perkembangan zaman. Artinya, kiai memainkan peranannya berdasarkan kebutuhan masyarakat umum. Kiai berubah wujud dari pengelola pondok pesantren menjadi seorang politisi. Kiai bisa berubah perannya dari seorang muballigh (da'i) menjadi sosok intelektual yang membangun sebuah hegemoni kekuasaan. Pergeseran peran kiai di masyarakat, berdasarkan paparan Ali Machsan Moesa, terbagi menjadi beberapa model peranan; Pertama, kiai spiritual, kiai advokasi, kiai politik adaptif, kiai politik mitra kritis ${ }^{44}$. Kedua, kiai pesantren, kiai tarekat, kiai politik, kiai panggung ${ }^{45}$. Ketiga,

40 Hasbullah, Sejarah Pendidikan Islam di Indonesia: Lintasan Sejarab Pertumbuban dan Perkembangan (Jakarta: Raja Grafindo Persada, 1995), 138.

41 Imam Bawani, Tradisionalisme dalam Pendidikan Islam (Surabaya: Al Ikhlas, 1993), 90.

42 Abdurrahman Wahid, Regenerasi Kepemimpinan dalam Pesantren (Jakarta: Pesantren I, 1996), 3.

${ }^{43}$ Dawam Rahardjo, Pesantren dan Pembaharuan (Jakarta: LP3ES, 1985), 11.

44 Tipologi ini dikutip dari desertasi Imam Suprayogo yang berjudul "Kiai Politik, Kiai Advokatif, dan Kiai Spiritual”. Dalam penjelasannya Kiai Spiritual adalah kiai yang hanya mengurus dan mengajar di pondok pesantren serta berkonsentrasi untuk beribadah. Kiai advokasi adalah kiai yang aktif mengajar di pondok pesantren namin ia masih sangat peduli terhadap pemberdayaan masyarakat. Kiai politik adaptif; yakni kiai yang peduli terhadap organisasi politik dan kekuasaan serta dekat dengan pemerintah. Kiai politik mitra kritis adalah kiai yang peduli terhadap organisasi politik, namun mereka kritis terhadap pemerintahan. (Lihat : Ali Machsan Moesa, Nasionalisme Kiai (Jogjakarta; LKiS, 2007), 64-65)

45 Adapun tipologi kedua ini didasarkan pada desertasi yang ditulis oleh Turmudi yang membagi kiai menjadi empat tipe. Kiai pesantren adalah kiai yang fokus untuk mengajar di Pesantren. Kiai tarekat adalah kiai yang aktivitasnya difokuskan pada pembangunan kecerdasan hati. Kiai politik adalah mereka yang memiliki perhatian

22 | Tarbiyatuna: Jurnal Pendidikan Islam; Volume 11, Nomor 1, Februari 2018 p-ISSN: 2085-6539; e-ISSN: 2242-4579 
kiai intelektual organik, kiai intelektual tradisional, kiai intelektual simultan ${ }^{46}$.

Ali Machsan Moesa sendiri membagi tiga model kiai menjadi tiga; kiai fundamentalis, kiai moderat, kiai pragmatis. Kiai fundamentalis adalah sekelompok kiai yang masih punya idealisme tentang berdirinya negara Islam. Nasionalisme berdasarkan pancasila bukanlah hal yang final. Apabila suatu saat formalisasi syari'at Islam bisa dijalankan, maka negara Islam (dar al Islam) wajib dilaksanakan. Kiai moderat adalah kiai yang berpendapat bahwa agama dan negara memiliki sikap simbiotis, konsep negara-bangsa (nation-state) yang ada seperti saat ini adalah yang paling cocok. Ketiga, kiai pragmatis. Mereka adalah kiai yang memiliki idealisme fundamentalis dan menganut universalisme Islam, namun mereka juga menyadari bahwa kondisi Indonesia tidak memungkinkan untuk berubah sebagai negara Islam. Oleh karenanya, mereka lebih memiliki mengikuti pandangan mainstream para kiai NU kiai $^{47}$. Kajian-kajian mengenai tipe kiai ini akan terus berkembang. Pasalnya, problem yang dihadapi masyarakat dan kebutuhan terhadap respon seorang kiai juga akan terus bertambah. Kiai, dari sisi keilmuan, memang tidak hanya terfokus pada keahliannya dalam agama, melainkan juga kehidupan sosial secara umum. Andree Feillard mengatakan bahwa, pada beberapa tahun terakhir pasca orde lama runtuh, hubungan kiai, santri, dan masyarakat tidak lagi paternalistik. Hubungan mereka berubah menjadi hubungan fungsional, dimana kiai berperan penguasa struktur yang menjalankan fungsi kepala adat, tokoh masyarakat dan bahkan pemimpin pemerintahan $^{48}$.

Dengan demikian, sangat mudah rasanya, apabila ingin menyebutkan bahwa sosok KH. Wahid Zaini Mun'im - selanjutnya disingkat Kyai Wahid, adalah seorang

untuk pengembangan organisasi NU dan terlibat dalam politik praksis. Kiai panggung adalah mereka yang fokusnya tercurahkan sebagai seorang da’i (muballigh). (Moesa, Nasionalisme, 65-66)

46 Tipologi ini didasarkan pada teori A. Gramsci dalam membentuk kekuatan hegemonik dalam masyarakat. Penelitian ini dilakukan oleh Warsono. Hasilnya dia membagi kiai menjadi tiga tipe, pertama, kiai intelektual organik, yakni tipe kiai yang menfikuskan tugasnya sebagai bagian dari struktur hegemoni masyarakat awam. Pada umumnya, kiai ini berada di bawah kekuasaan dan menjalankan fungsinya sesuai ide pembangunan nasional. Kedua, kiai intelektual tradisional, yaitu mereka yang memiliki otonomi dan tidak terpengaruh oleh kelompok dominan. Kiai tradisional biasanya lebih dekat dengan masyarakat dan melakukan penyadaran sesuai dengan basis keilmuannya sendiri. Ketiga, kiai intelektual simultan. Mereka adalah para kiai yang menjaga jarak dengan kekuasaan dan umumnya berkonsentrasi mengajar di pesantren dan menjalankan transformasi kemasyarakatan. (Moesa, Nasionalisme, 67-68)

47 Moesa, Nasionalisme, 281-295

48 Andree Fillard, Nu Vis a Vis Negara (Yogyakarta: LKiS, 1995), 78. 
pemimpin yang membasiskan aspek-aspek perlakuannya pada normativitasparadigmatik spiritual leadership. Untuk lebih memudahkan penulis akan membingkainya sebagaimana tabel berikut ini:

Tabel 1.1

Dimensi dan Behavioral Stance of Kyai Wahid as Spiritual Leadership

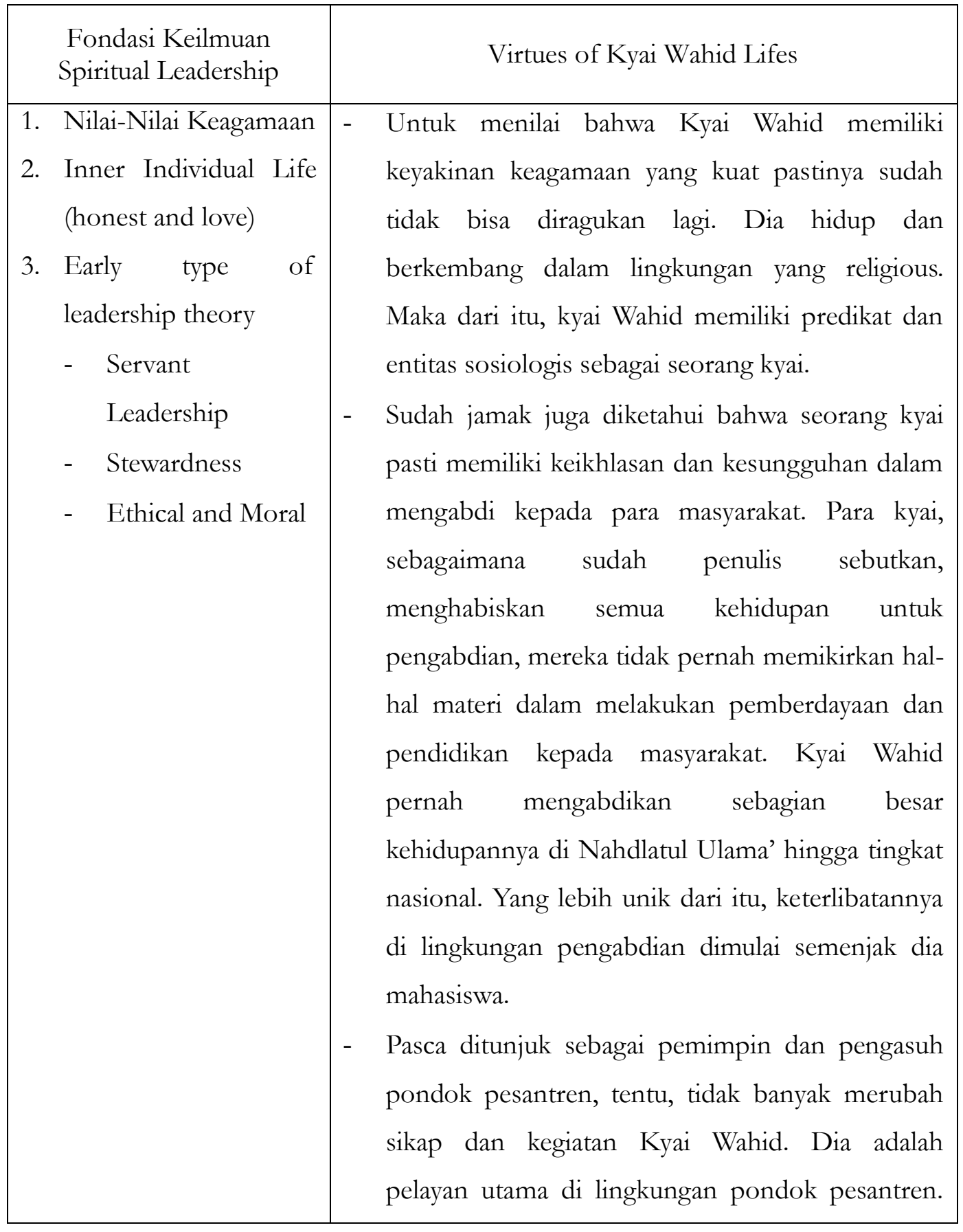




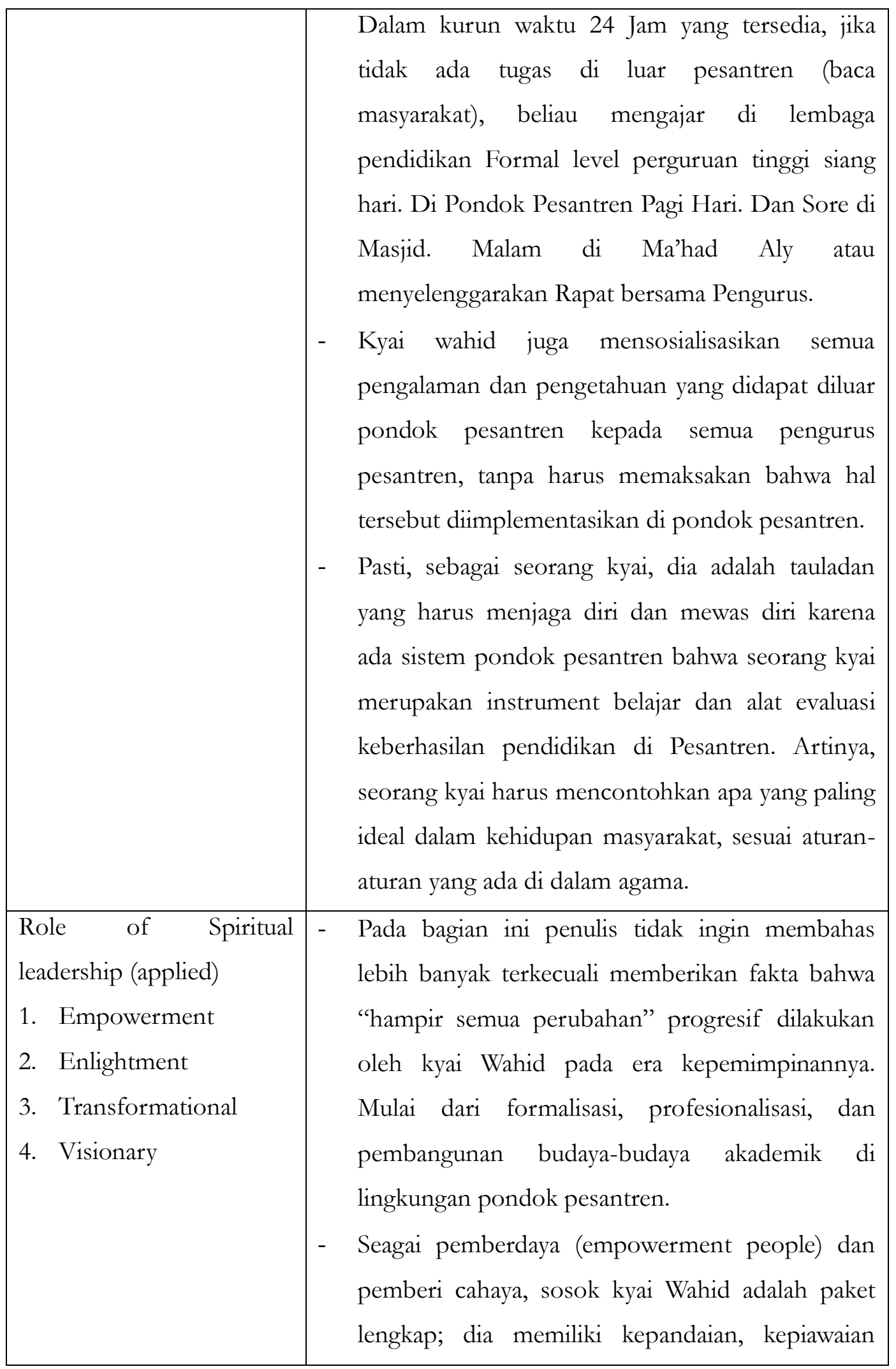




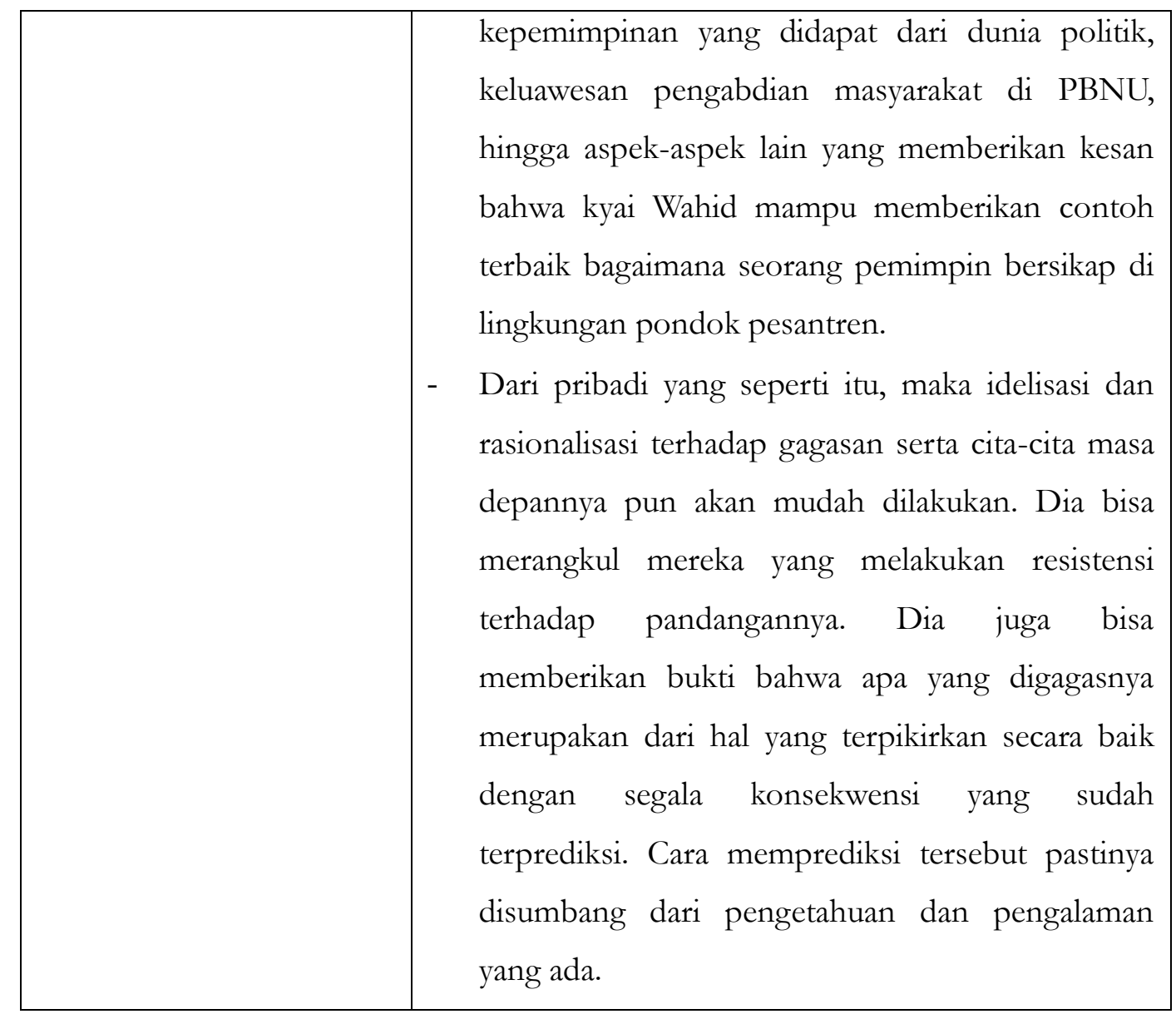

Berdasarkan teori, data, dan apa yang sudah penulis ungkapkan di atas, maka seorang spiritual leadership bisa disederhakan sebagai sosok yang sudah selesai pada persoalan dan kepentingan pribadinya. Mereka (para pemimpin spiritual) merupakan sosok yang meng-ikhlaskan dan menghibahkan semua kehidupan untuk mencapai visi, misi, dan program kepemimpinannya, melalui cara memahami, melayani, dan membimbing kea rah perubahan yang diinginkan. Apapun bentuk-bentuk perubahan yang diinginkan. Termasuk, dalam konteks kajian ini adalah membentuk profesionalitas dan membangun budaya unggul dalam pengelolaan lembaga pendidikan Islam. Kepemimpinan spiritual, kalau harus digenerilisasi dan dipostulasi ulang dalam konteks ke-Indonesiaan, hal ini bisa diletakkan kepada sosok kyai. Sosok yang tidak pernah tidur demi melayani, membimbing, dan memberikan contoh terbaik kepada masyarakat sekitar mereka. 


\section{Kesimpulan}

Pada kesimpulannya, melalui cara berfikir dimensi spiritualitas ini, penulis tidak pernah mengkhawatirkan apa perubahan yang diinginkan oleh seorang pemimpin. Dimensi spiritualitas, berarti menghidupkan dan menggiring seseorang melaui cara-cara yang menyentuh rasa, atau dalam bahasa kepemimpinan hari ini adalah memimpin dengan hati. Memimpin dengan merasakan apa yang bawahan rasakan. Memimpin dengan pendekatan persuasive bukan coercive. Memimpin dengan memberi contoh terlebih dahulu, dibandingkan harus memberi idealisasi dan rasionalisasi kepada bawawah akan ide yang diinginkannya. Sebagai ending dari tulisan ini, penulis ingin menceritakan satu virtues (kebajikan) seorang Kyai As'ad Syamsul Arifim (allah Yarham) terkait dengan bagaimana sesungguhnya seorang kyai mengajak masyarakat. Cerita ini penulis dapatkan dari Kyai Hasan Abdul Wafi, kala masih mengaji di Pondok Pesantren Nurul Jadid.

Ceritanya begini, pada suatu ketika, ada anak yang setiap hari memakan gula tanpa henti. Dampaknya, si anak ini kemudian tidak mau memakan nasi sebagaimana biasanya. Orang tua anak ini kemudian menghadap Kyai As'ad dan menceritakan problem anaknya. Kyai As'ad menjawab 'Silahkan pulang dulu, lalu kembali lagi seminggu lagi kesini'. Setelah orang tua ini pulang, Kyai As'ad menginstruksikan isterinya untuk memasak apapun tanpa gula, mulai dari teh hingga makanan lainnya. Seminggu kemudian, kyai As'ad ketemu dengan orang tua itu, dan memberikan air yang sudah diberi do'a dan keyakinan. Singkat cerita, sehari setelah dari Kyai As'ad orang tua itu kembali, dan memberi tahu bahwa anaknya sudah mau makan nasi lagi. Sudah berhenti makan gula dan memakannya sebagaimana kadar dan normalnya orang membutuhkan rasa manis pada makanan atau minuman. Penulis kira, itulah yang sejak awal penulis konstruksikan, bahwa kyai adalah episteme terbaik untuk menginstrumentasi kepemimpinan spiritual.

\section{Referensi}

Bawani, Imam., Tradisionalisme dalam Pendidikan Islam, Surabaya: Al Ikhlas, 1993

Dimmock, Clive et,al, Educational Leadership: Culture and Diversity, London: Sage Publication, 2005 
Fillard, Andree., Nu Vis a Vis Negara, Jogjakarta: LkiS, 1995

Hargreaves, Andy \& Dean Fink, "Succeeding Leader; Supply and Demand" dalam Robert E White (edited) Principal in Succeesion; Transfer and Rotation In Educational Administration, New York: Springer 2011

Hasbullah, Sejarah Pendidikan Islam di Indonesia: Lintasan Sejarah Pertumbuhan dan Perkembangan, Jakarta: Raja Grafindo Persada, 1995

Holilurarahman, "Dialektika-Progresif Kepemimpinan Pesantren dan Integrasi Ilmu Pengetahuan" Jurnal al-Afkar Vol. 1, No. 1, 2012

Houdson, Paul D., Spritual in Educational Leadership New York: Hope Foundation, 2008

KH. Abdul Hamid Wahid, Wawancara, Probolinggo, 25 April 2016

KH. Faiz AHZ, Profil Pondok Pesantren Nurul Jadid, Koordinatorat PP Nurul Jadid, Probolinggo, 2010

KH. Moh Zuhri Zaini, Pengasuh PP. Nurul Jadid Wawancara, Probolinggo 16 April 2016

KH. Najiburrahman Wahid, Wawancara, Probolinggo, 20 April 2016

Koentjaraningrat, Kebudayaan Jawa, Jakarta: Balai Pustaka, 1984

Madjid, Nurcholish., Bilik-Bilik Pesantren, Jakarta: Paramadina, 1997

Maiko Yasuno, "The Role of Spirituality in Leadership for Social Change", NewsLetter Spirituality in Education, Vol. 4, Issue. 3 June 2008

Moesa, Ali Machsan., Nasionalisme Kiai, Jogjakarta; LkiS, 2007

Nada Korac-Kakabadse, Alexander Kouzmin and Andrew Kakabadse, "Spirituality and leadership \& praxis", Journal of Psycology, Vol. 1, No. 2, 2012

Pedoman Pelaksanaan Orientasi Santri Baru, PP. Nurul Jadid, 2010

Rahardjo, Dawam., Pesantren dan Pembaharuan, Jakarta: LP3ES, 1985

Rudy al Hana, "Kebertahanan Pondok Pesantren; antara integrasi dan adaptasi", Jurnal Pendidikan Agama Islam, Vol. 1, No. 2, 2012

Wahid, Abdurrahman., Regenerasi Kepemimpinan dalam Pesantren, Jakarta: Pesantren I, 1996

Ziemek, Manfred., Pesantren dalam Pmbaharuan Sosial, Transleted By Butche B Soendjojo, Jakarta: P3M, 1986 